\title{
Międzynarodowa pozycja Unii Europejskiej w warunkach niestabilności południowego i wschodniego sąsiedztwa
}

\section{Wstęp}

Upadek muru berlińskiego i rozpad Związku Radzieckiego przez wielu badaczy stosunków międzynarodowych - z Francisem Fukuyamą na czele - postrzegany był jako swego rodzaju „,koniec historii”, koniec konfliktów i sporów motywowanych ideologicznie (Fukuyama, 1996). I co ważne, Zachód - jako zwycięzca tej bipolarnej rywalizacji - uważał, że nastał czas demokracji neoliberalnej, bezpieczeństwa i pokojowego współistnienia państw. Już w połowie lat 90. XX wieku konieczna była redefinicja poglądów na temat pozimnowojennego porządku światowego. Natomiast z perspektywy 2017 roku ten pogląd wydaje się jeszcze bardziej naiwny i niemający odzwierciedlenia w rzeczywistości międzynarodowej. Potwierdzeniem błędności takiego sposobu postrzegania świata są wydarzenia - mając na uwadze najbliższe sąsiedztwo Unii Europejskiej - w postaci arabskiej wiosny czy trwających wojen w Syrii i na Ukrainie.

Analizując międzynarodową pozycję Unii Europejskiej, należy mieć na uwadze, że Wspólnota boryka się z licznymi kryzysami o charakterze wewnętrznym i zewnętrznym, które mogą wpłynąć na jej funkcjonowanie w przyszłości. Ich skutki mogą podważyć obecny model integracji i doprowadzić nawet do znaczącej transformacji UE oraz wpłynąć na jej międzynarodową pozycję. Źródłem obecnych kryzysów są poważne różnice zdań pomiędzy państwami członkowskimi co do radzenia sobie z wyzwaniami tak wewnętrznymi, jak i zewnętrznymi stojącymi przed Unią Europejską. Pośród najważniejszych kryzysów wymienić należy kryzys w strefie euro, stosunek do uchodźców i migrantów z Bliskiego Wschodu i Afryki oraz zróżnicowane podejście do Rosji (w kontekście aneksji Krymu i konfliktu na ukraińskim Donbasie). Kryzysy te ilustrują głębokie podziały nie tylko pomiędzy państwami członkowskimi, ale również w ramach poszczególnych państw.

Unia Europejska staje się aktorem globalnym w wielu wymiarach. Decyduje o tym nie tylko potencjał ekonomiczny, ale również społeczny i kulturowo-cywilizacyjny. Pełnienie roli gracza światowego wymusza na Unii ułożenie poprawnych relacji nie tylko z odległymi, choć ważnymi państwami i/lub regionami, lecz również ze swoim najbliższym sąsiedztwem. W tym też celu Unia Europejska poprzez ustanowienie w 2004 roku Europejskiej Polityki Sąsiedztwa dąży do stabilizowania i poprawiania swoich relacji z państwami położonymi na granicach południowych i wschodnich. 


\section{Unia Europejska jako aktor na arenie międzynarodowej}

Podejmując próbę analizy międzynarodowej pozycji Unii Europejskiej, można posłużyć się kryterium, które po raz pierwszy zostało zastosowane przez Christophera Hilla w 1992 roku (Hill, 1998, s. 18). Wysunął on wtedy ideę luki pomiędzy możliwościami a oczekiwaniami w odniesieniu do europejskiej polityki zagranicznej. Inaczej do kwestii oceny zdolności Unii odniósł się Fraser Cameron, który uważał, że Unia nie powinna być jedynie płatnikiem, ale również graczem na arenie międzynarodowej (Cameron, 2003). Jeszcze inny element służący ocenie skuteczności działań międzynarodowych państw członkowskich pojawił się w 1973 roku, kiedy to administracja amerykańska proklamowała Rok Europy. Wówczas to Henry Kissinger wyraził zdumienie, że Wspólnota Europejska nie była w stanie desygnować jednej osoby, z którą można by prowadzić rozmowy i konsultacje dotyczące wszelkich aspektów aktywności międzynarodowej. Jednak jak stwierdził francuski ambasador w Stanach Zjednoczonych, Europie trudno byłoby wypowiadać się jednym głosem w tak wielu kwestiach. Powyższe sformułowania ilustrują szereg problemów związanych z ustanowieniem i funkcjonowaniem polityki zagranicznej na szczeblu europejskim. Dotyczą one nie tylko stworzenia struktur i mechanizmów podejmowania decyzji, ale również czy przede wszystkim woli politycznej demonstrowanej przez państwa członkowskie w sytuacjach kryzysowych. Niejednokrotnie bowiem pomimo istnienia określonych procedur decyzyjnych, państwom członkowskim z uwagi na odmienne interesy trudno jest wypracować wspólne stanowisko lub podjąć wspólne działania. Jednym z przykładów może być reakcja Unii Europejskiej na atak Stanów Zjednoczonych na Irak w 2003 roku. Brytyjski tygodnik „The Economist", oceniając stan dyplomacji europejskiej w tym kontekście, nadał znamienny tytuł jednemu z artykułów: Zjednoczeni $w$ teorii, podzieleni w praktyce (Podraza, 2003, s. 381-382).

W odróżnieniu od bardzo wysokiego poziomu integracji gospodarczej i walutowej, który został osiaggnięty w ramach Unii Europejskiej przez stworzenie rynku wewnętrznego oraz wprowadzenie wspólnej waluty w wielu państwach członkowskich, unifikacja polityczna nigdy nie weszła w decydująca fazę realizacji. Taki stan rzeczy wynikał $\mathrm{w}$ dużej mierze $\mathrm{z}$ nieudanych prób zainicjowania integracji politycznej w latach 50., kiedy to nie doszło ostatecznie do stworzenia Europejskiej Wspólnoty Obronnej i Europejskiej Wspólnoty Politycznej. Fiaskiem zakończyły się również negocjacje prowadzone na początku lat 60. w ramach komitetu Foucheta, jakkolwiek realizacja pomysłu powołania Europejskiej Unii Politycznej w wersji zaproponowanej przez prezydenta Charles'a de Gaulle'a mogłaby doprowadzić do marginalizacji Wspólnot Europejskich i ograniczenia wpływów amerykańskich na kontynencie europejskim. Kooperacja w zakresie polityki zagranicznej została zainicjowana dopiero w 1970 roku, kiedy powstała Europejska Współpraca Polityczna o wyraźnym międzyrządowym charakterze (Zięba, 2003, s. 26-46). Mechanizm ten początkowo był wyraźnie oddzielony od Wspólnot Europejskich, więc istniała dychotomia pomiędzy polityką zagraniczną a zewnętrznymi stosunkami gospodarczymi. Dopiero później nastąpiło zbliżenie pomiędzy dwoma procesami decyzyjnymi, w szczególności nastąpiło to w Jednolitym Akcie Europejskim, który wszedł w życie 
1 lipca 1987 roku. Również w latach 80. rozszerzono zakres dyskutowanych problemów najpierw o polityczne, a później o ekonomiczne aspekty bezpieczeństwa. Pomimo tych zmian na ogół zauważano ograniczenia EWP i wobec tego zastąpiono ten mechanizm na mocy traktatu z Maastricht Wspólną Polityką Zagraniczną i Bezpieczeństwa. Co ważne, powstanie WPZiB zbiegło się w czasie z niezwykle istotnymi zmianami na arenie międzynarodowej w wyniku zakończenia zimnej wojny. To właśnie wyzwania zewnętrzne, a nie tylko dążenie do pogłębiania unifikacji politycznej, miały wpływ na próby wzmocnienia współpracy państw członkowskich w zakresie polityki zagranicznej, bezpieczeństwa, ale również obrony (Treacher, 2004, s. 49-50). Wspólna inicjatywa kanclerza Niemiec Helmuta Kohla i prezydenta Francji François Mitterranda, która doprowadziła ostatecznie do stworzenia drugiego filaru Unii Europejskiej, została wysunięta w obliczu radykalnych przemian w państwach Europy Środkowo-Wschodniej oraz zjednoczenia Niemiec (Edwards, Nuttall, s. 86-87). Innym ważnym impulsem na początku lat 90. była wojna w Zatoce Perskiej. Jednak pomimo wyraźnej potrzeby stworzenia skutecznych mechanizmów wypracowywania polityki zagranicznej, bezpieczeństwa i obrony oraz konieczności jednolitego wypowiadania się i działania na arenie międzynarodowej, negocjacje, które zakończyły się przyjęciem traktatu z Maastricht, wykazały, że linie sporu pomiędzy państwami członkowskimi były niejako „klasyczne” (Podraza, 2001, s. 145-146). Zasadnicze kontrowersje pomiędzy państwami członkowskimi w zakresie polityki zagranicznej, bezpieczeństwa i obrony dotyczą sporu pomiędzy koncepcjami międzyrządową a ponadnarodową oraz pomiędzy wizjami transatlantycką a europejską. Istotny jest również konflikt w sprawie zakresu i sposobu uwzględnienia polityki obronnej. W konflikcie tym nie występują jedynie państwa opowiadające się za wizjami transatlantycką bądź europejską, ale również, z zupełnie innych powodów, kraje neutralne (Stahl, Boekle, Nadoll, Jóhannesdóttir, 2004, s. 418).

Głównym uzasadnieniem reform z lat 90. XX wieku i późniejszego okresu było uczynienie z Unii Europejskiej, biorąc pod uwagę jej potencjał gospodarczy i ludnościowy, aktora globalnego, który mógłby skutecznie podejmować działania międzynarodowe w wielu różnych obszarach. Marise Cremona wymienia kilka podstawowych ról UE (Cremona, 2004, s. 553-565): 1) UE jako laboratorium i model integracji; 2) UE jako gracz rynkowy; 3) UE jako twórca reguł; 4) UE jako stabilizator; 5) UE jako magnes i sąsiad. Z kolei Ryszard Zięba dokonuje podziału ról pełnionych przez Unię Europejską na trzy podstawowe kategorie (Zięba, 2003, s. 244-264): 1) międzynarodowe role ekonomiczne (rola lidera zrównoważonego rozwoju oraz wzorca pomyślnej i kompleksowej integracji; rola największego udziałowca w handlu światowym; rola dostarczyciela największej pomocy rozwojowej; rola donatora największej pomocy humanitarnej); 2) międzynarodowe role polityczne i w zakresie bezpieczeństwa (rola aktywnego aktora dyplomatycznego; rola stabilizatora pokoju i bezpieczeństwa międzynarodowego); 3) rola atrakcyjnego ośrodka cywilizacyjnego i promotora wartości kultury europejskiej. Analizując powyższe zestawienia, należy dojść do wniosku, że dyskusje w ramach kolejnych konferencji międzyrządowych koncentrowały się przede wszystkim na niektórych aspektach funkcji stabilizacyjnych wypełnianych przez Unię Europejską, czyli dotyczyły Wspólnej Polityki Zagranicznej i Bezpieczeństwa oraz realizowanej w jej 
ramach od 1999 roku Europejskiej Polityki Bezpieczeństwa i Obrony ${ }^{1}$. Przemiany mają również na celu zwiększenie skuteczności Unii w zakresie aktywności dyplomatycznej.

Podstawowe dylematy, które pojawiły się w latach 90. XX wieku, dotyczyły kwestii, na ile w zakresie polityki zagranicznej, bezpieczeństwa i obrony można było, po pierwsze, wprowadzić nawet w ograniczonym zakresie rozwiązania ponadnarodowe, a po drugie, czy istniała możliwość zróżnicowania integracji w tym obszarze. Działania podejmowane w latach 90. i później były podyktowane perspektywą przyjęcia nowych państw członkowskich, ale także koniecznością zwiększenia skuteczności ówczesnej Unii Europejskiej. Niekiedy wyrażano bowiem niezadowolenie z sytuacji, w której polityka zagraniczna Unii była raczej postrzegana jako suma polityk suwerennych państw członkowskich, a nie jako polityka realizowana przez ponadnarodową strukturę (Koutrakos, 2003, s. 73-74). Uważano, że po sukcesie znaczących projektów w dziedzinie integracji gospodarczej, tj. przede wszystkim po dokończeniu tworzenia rynku wewnętrznego w 1992 roku, potrzebna była wielka idea dotycząca unifikacji politycznej. Wskazywano, że takim wyzwaniem może być realizacja polityki w zakresie bezpieczeństwa i obrony. Zainicjowanie integracji militarnej w ramach Unii Europejskiej, przy uwzględnieniu szeregu ograniczeń tego procesu, stanowiło bardzo istotne przełamanie pewnego tabu funkcjonującego od momentu nieudanej próby stworzenia Europejskiej Wspólnoty Obronnej (Rummel, 2002, s. 455-457). Jednak unifikacja w tym zakresie rodzi szereg problemów przede wszystkim związanych z ewentualnością uelastycznienia współpracy. Biorąc pod uwagę zróżnicowanie poglądów pomiędzy państwami członkowskimi, należy zauważyć, że kraje prezentujące wyraźną opcję europejską na ogół dążą do pogłębiania kooperacji militarnej, co może prowadzić do znacznego zróżnicowania integracji politycznej.

Nie można zapominać, że istnieje szereg czynników ograniczających aktywność Unii Europejskiej na arenie międzynarodowej. Stałym problemem jest kwestia ,aktorstwa" (actorness) Unii na arenie międzynarodowej. Problem ten jest analizowany od dziesięcioleci, ale do tej pory nie został rozwiązany przez decyzje polityczne, nawet po przyjęciu traktatu lizbońskiego, który wszedł w życie 1 grudnia 2009 roku. Po traktacie lizbońskim Unia jest lepiej przygotowana i zorganizowana, ale generalnie nie jest silniejszym graczem na arenie światowej - UE nadal brakuje politycznej woli mówienia „,jednym głosem” w przypadku ważnych kryzysów międzynarodowych. Przykładowo Stany Zjednoczone postrzegają Europę jako formalnie zjednoczonego, ale słabego partnera. Ponadto największe państwa członkowskie Unii, zwłaszcza Francja i Wielka Brytania (na skutek Brexitu niedługo będzie poza UE) jako stali członkowie Rady Bezpieczeństwa ONZ, ale także Niemcy, są bardziej skłonne do prowadzenia własnej polityki zagranicznej niż do koordynowania stanowisk w ramach Unii Europejskiej, chyba że służy to realizacji narodowych interesów. Reasumując, można więc dojść do oczywistego wniosku, który między innymi został zwerbalizowany przez Johna Petersona, że Unia Europejska cierpi z powodu kilku przewlekłych problemów, tj. rozbicia, niespójności oraz słabego przywództwa (Peterson, 2008, s. 202). Co więcej,

${ }^{1}$ EPBiO powstała jako wynik kompromisu w 1999 roku na mocy decyzji Rady Europejskiej w Kolonii (czerwiec 1999) i w Helsinkach (grudzień 1999). EPBiO znalazła się w obrębie Traktatu o UE na mocy traktatu z Nicei. 
mają w jej ramach miejsce wszelkie rodzaje rywalizacji: pomiędzy rządami państw członkowskich, pomiędzy instytucjami UE i ostatecznie między nimi a krajowymi ministerstwami spraw zagranicznych.

Mówiąc o pozycji międzynarodowej UE, warto odnieść się również do prognoz przedstawionych przez Europejski System Analiz Strategicznych i Politycznych (ESPAS). Według autorów tego raportu, UE w dalszym ciagu będzie cieszyć się jednym z najwyższych na świecie dochodów w przeliczeniu na mieszkańca, ale jej udział w globalnym PKB skurczy się w latach 2010-2030 z 23,1\% do 15,5\%. Sytuacja ta powoduje, że około 2030 roku 90\% światowego wzrostu PKB będzie mieć miejsce poza obszarem Unii Europejskiej (Światowe, 2017).
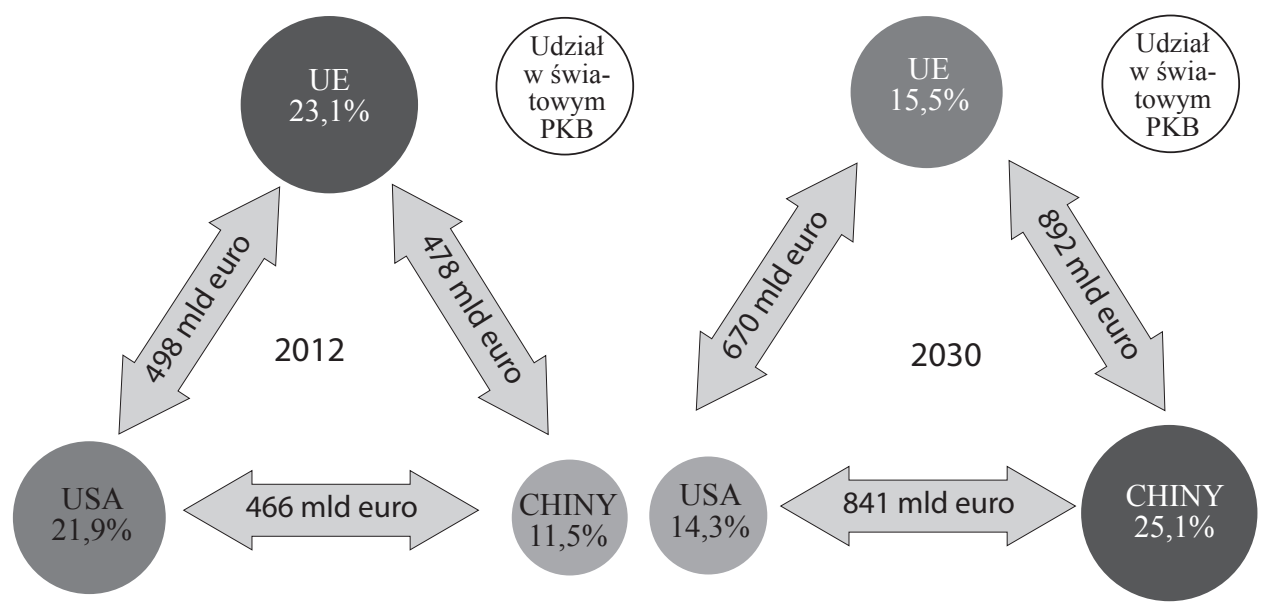

Rys. 1. Dwustronne przepływy handlowe i udział trzech potęg gospodarczych w światowym PKB

Źródło: Światowe tendencje do $2030 \mathrm{r}$ :: czy UE jest w stanie sprostać przysztym wyzwaniom?, „Europejski System Analiz Strategicznych i Politycznych (ESPAS)", Luksemburg 2017, http://espas.eu/orbis/sites/ default/files//generated/document/en/espas-report-2015pl.pdf, s. 27.

\section{Europejska Polityka Sąsiedztwa: od „kręgu przyjaciól” do „kręgu ognia”}

Przejawem i potwierdzeniem zmiany sposobu postrzegania przez Unię Europejską najbliższego sąsiedztwa był rok 2004. Rozszerzenie UE w kierunku wschodnim w 2004 roku spowodowało konieczność zmiany postrzegania sytuacji geopolitycznej w Europie Środkowo-Wschodniej. Wychodząc naprzeciw nowym wyzwaniom, Unia Europejska stworzyła Europejską Politykę Sąsiedztwa (EPS), której jednym z głównych zadań było osiagnięcie stabilizacji w południowym i wschodnim sąsiedztwie Wspólnoty. Zadanie to miało zostać zrealizowane przez stworzenie wokół granic zewnętrznych UE - odnosząc się do słów Romano Prodiego - „kręgu przyjaciół” („I want to see a 'a ring of friends' surrounding the Union and its closest European neighbours, from Morocco to Russia and the Black Sea") (Prodi, 2002), stabilnego i w perspektywie demokratyzującego się sąsiedztwa. Warto tutaj dodać, że zacieśnianie stosunków 
między UE a partnerami południowymi czy wschodnimi w większości popierane było przez państwa członkowskie posiadające swoje interesy na tych obszarach. W realizacji południowego wymiaru (sąsiedztwa) szczególnie aktywne były państwa takie jak: Francja, Hiszpania czy też Portugalia. Natomiast Polska była aktywna we wschodnim sąsiedztwie (po rozszerzeniu z 2004 roku). Z perspektywy 2017 roku sytuacja bezpieczeństwa w regionie południowym i wschodnim w sposób jednoznaczny pokazuje, że cel EPS nie został osiagnięty. Wojna na Ukrainie, w Syrii, w Libii oraz ogólna niestabilność sąsiedztwa UE powodują, że lepszym terminem do określenia sytuacji na tych obszarach jest termin „krag ognia” (,a ring of fire”).

Warto wspomnieć, że po 2004 roku, czyli w kolejnych latach funkcjonowania EPS, zgłaszane były liczne projekty dotyczące modyfikacji w celu uskutecznienia jej oddziaływania na sytuację południowych i wschodnich sąsiadów. Warto tutaj wspomnieć o propozycjach takich jak: EPS Plus (European Neighbourhood Policy Plus) z 2006, Synergia Czarnomorska (Black Sea Synergy) z 2007, Wzmocniona EPS (Enhanced European Neighbourhood Policy), Unia dla Śródziemnomorza (Union for the Mediterranean) z 2008 oraz Partnerstwo Wschodnie (Eastern Partnership) z 2009 roku (Lesińska, Stępniewski, 2016, s. 5-13). Poniżej ukazano zestawienie poszczególnych koncepcji reformy EPS po 2004 roku, z położeniem nacisku na zasięg terytorialny.

Tabela 1

\section{Zasięg terytorialny Europejskiej Polityki Sąsiedztwa Unii Europejskiej (oraz innych projektów reformujących EPS)}

\begin{tabular}{|c|c|c|c|c|}
\hline Koncepcja & $\begin{array}{c}\text { Inicjatywa } \\
\text { Nowego } \\
\text { Sąsiedztwa }\end{array}$ & $\begin{array}{l}\text { Wschodni } \\
\text { wymiar UE }\end{array}$ & $\begin{array}{c}\text { Koncepcja „,szerszej } \\
\text { Europy" }\end{array}$ & Europejska Polityka Sąsiedztwa \\
\hline $\begin{array}{l}\text { Zasięg te- } \\
\text { rytorialny }\end{array}$ & $\begin{array}{l}\text { Białoruś, } \\
\text { Mołdawia, } \\
\text { Ukraina }\end{array}$ & $\begin{array}{l}\text { Białoruś, } \\
\text { Mołdawia, } \\
\text { Ukraina, } \\
\text { Rosja }\end{array}$ & $\begin{array}{l}\text { 1) wschodni sąsiedzi: } \\
\text { Białoruś, Mołdawia, } \\
\text { Ukraina i Rosja; } \\
\text { 2) południowi sąsiedzi: } \\
\text { państwa basenu Mo- } \\
\text { rza Śródziemnego }\end{array}$ & $\begin{array}{l}\text { 1) wschodni sąsiedzi: Białoruś, } \\
\text { Mołdawia, Ukraina, Armenia, } \\
\text { Azerbejdżan i Gruzja; } \\
\text { 2) południowi sąsiedzi: Algieria, } \\
\text { Egipt, Izrael, Jordania, Liban, } \\
\text { Libia, Maroko, Autonomia Pale- } \\
\text { styńska, Syria, Tunezja }\end{array}$ \\
\hline
\end{tabular}

Źródło: Opracowanie własne.

Warto pamiętać, że w sąsiedztwie UE znajdują się również państwa, które nie zostały objęte tą polityką, a posiadają rozwinięte stosunki, lub też ich stosunki opierają się na innych zasadach niż te ustanowione przez EPS. Oprócz EPS istnieją również polityki: 1) skierowane do państw EFTA/EEA(Islandia, Szwajcaria, Norwegia, Liechtenstein), które to państwa nie są postrzegane jako potencjalni kandydaci do członkostwa, lecz jako państwa, z którymi Unia pragnie zacieśniać relacje; 2) polityka skierowana do Bałkanów Zachodnich (Albania, Bośnia i Hercegowina, Macedonia, Czarnogóra, Serbia) i Turcji; 3) „strategiczne partnerstwo” z Rosją. Dlatego też po 2004 roku możemy zidentyfikować pięć regionalnych obszarów szeroko rozumianego sąsiedztwa UE (patrz poniższy rysunek) - inaczej zwanego szerszym sąsiedztwem UE:

1) Europa Północna (Northern Europe);

2) Wymiar śródziemnomorski (Mediterranean) (obecnie Unia dla Śródziemnomorza); 
3) Bałkany (Balkans);

4) Region Morza Czarnego (Black Sea Region);

5) Wymiar wschodni (Eastern Dimension).

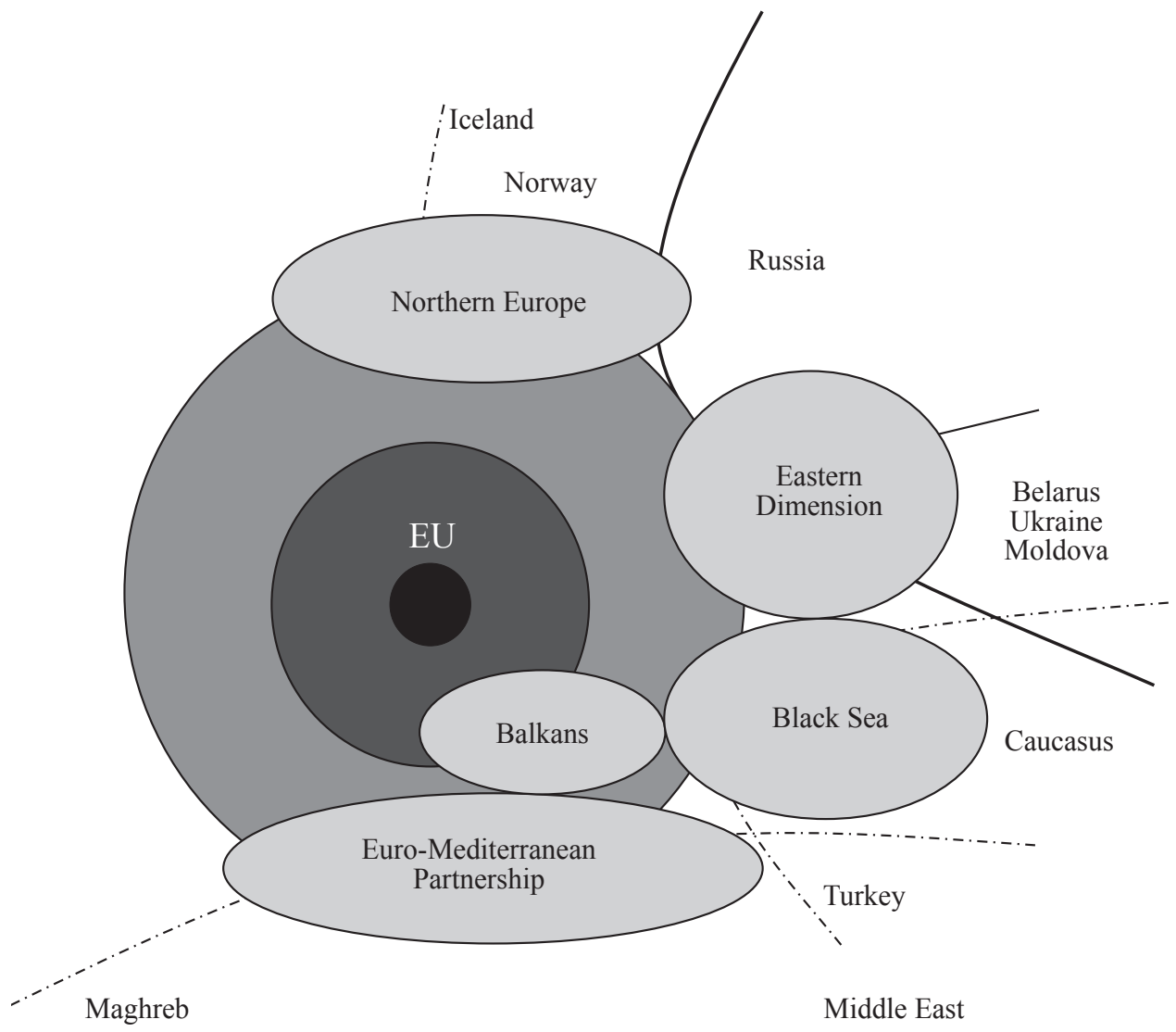

Rys. 2. Pięć obszarów wyodrębnionych w sąsiedztwie Unii Europejskiej

Źródło: F. Tassinari (2005), Security and Integration in the European Union Neighbourhood. The Case for Regionalism, CEPS Working Document, no. 226/July, Brussels, http://aei.pitt.edu/6667/1/1251_226.pdf.

Jak wskazano powyżej, pomimo przemian politycznych na obszarze południowego i wschodniego sąsiedztwa, jakie miały miejsce w ciagu ostatniej dekady, EPS nie została radykalnie zmieniona, jedynie poddana modyfikacjom, a tym samym nie przyczyniła się do poprawienia sytuacji w regionie, szczególnie w zakresie bezpieczeństwa. Tzw. arabska wiosna, wojna Rosji z Gruzją w sierpniu 2008 roku, a następnie wojna hybrydowa Rosji z Ukrainą od 2014 roku potwierdzają, że EPS nie jest polityką efektywną i nie zapobiega konfliktom w bliskim sąsiedztwie Unii Europejskiej. Dodatkowo, dokonane przez Komisję Europejską przeglądy EPS w 2011 roku (wynik arabskiej wiosny) oraz w latach 2014-2015 (powody: konflikt zbrojny Rosji z Ukraina, masowe migracje z Bliskiego Wschodu i Afryki do Europy) potwierdziły niewielką skuteczność tej polityki oraz wskazały na konieczność zmian w sposobie jej 
funkcjonowania. Według Komisji Europejskiej, w najbliższych latach EPS powinna koncentrować się na stabilizacji, większej współodpowiedzialności, bezpieczeństwie i rozwoju gospodarczym krajów sąsiedztwa. Jak zauważył komisarz UE ds. polityki sąsiedztwa i negocjacji w sprawie rozszerzenia Johannes Hahn, „najważniejszym zadaniem w tej chwili jest zapewnienie stabilizacji w naszym sąsiedztwie. Konflikty, terroryzm i radykalizacja postaw stanowią zagrożenie dla nas wszystkich. Brak bezpieczeństwa jest też jednak skutkiem ubóstwa, korupcji i złego sprawowania rządów. Dlatego tam, gdzie istnieje taka potrzeba, skoncentrujemy się w kontaktach z partnerami na łączących nas wspólnych interesach" (Przeglad, 2015).

Odnosząc się do południowego sąsiedztwa, należy wskazać, że świat arabski po tzw. arabskiej wiośnie przypomina obraz po katastrofie. Istotne jest to, że „arabska wiosna pokazała, że model państwa oparty na stagnacji i dyktaturze jest już nie do utrzymania; obecny kryzys jest w znacznym stopniu efektem jego trwania przez poprzednie półwiecze. To zaś daje szansę, lecz - jak powiedział syryjski pisarz Chaled Chalifa - 'życie zawsze stwarza wspaniałą okazję, byś wykpił swoich wrogów, pod warunkiem że uda ci się wyrwać z ich rąk”" (Warszawski, 2017).

Z kolei we wschodnim sąsiedztwie mamy konflikt na Donbasie, który wpływa na stabilność Europy Wschodniej i stawia pod znakiem zapytania sytuację tego obszaru. Prezydent Estonii w czasie Global Forum w Warszawie 7 lipca 2017 roku słusznie zauważyła, że konflikt na Ukrainie może trwać dziesięciolecia (Prezydent Estonii, 2017). Wynika to z faktu, że „Kreml jednak podejmuje próby politycznego zdominowania tych europejskich obszarów, które przez dłuższy czas były zależne lub okupowane przez imperium sowieckie, a dziś chcą się rozwijać samodzielnie, niezależnie od Moskwy. To rodzi kontrreakcję ze strony reżimu Putina. Jako taki obszar można wskazać większość państw Partnerstwa Wschodniego położonych między Unią a Rosją czy region zachodnich Bałkanów. Uwagę należy jednak zwrócić przede wszystkim na Ukrainę" (Kubilius, 2017).

\section{Wschodnie sąsiedztwo Unii Europejskiej w cieniu Federacji Rosyjskiej}

Pomimo że Unia Europejska nie jest na ogół ujmowana jako tradycyjna potęga, nie brak oczywiście opinii, że następuje transformacja Unii polegająca na odejściu od rozwijania projektu pokojowego bazującego na cywilnej agendzie w kierunku aktora współzawodniczącego geopolitycznie, którego racja stanu koliduje z jej normatywnymi zobowiązaniami (Sakwa, 2015, s. 553-554). Zgodnie z takim podejściem Unia Europejska albo przyłącza nowe terytoria, co oczywiście ma miejsce w ramach procesów akcesyjnych, albo dąży do stworzenia strefy wpływów przez pogłębianie relacji gospodarczych i politycznych z państwami sąsiedzkimi. W takich kategoriach można by chociażby interpretować rozwój stosunków z Ukraina, która pomimo braku obietnicy przyszłego członkostwa podpisała w 2014 roku umowę stowarzyszeniową z UE.

Zasadne w tym kontekście jest postawienie pytania, czy przyczyn agresywnych działań Moskwy należy doszukiwać się w polityce Zachodu, w tym Unii Europejskiej, czy też jest to wynik bardzo ograniczonej transformacji Rosji, która może być opisywana jako państwo nie w pełni demokratyczne. Innymi słowy, czy działania Unii Euro- 
pejskiej i NATO, realizujące politykę poszerzenia, są na tyle istotnym wyzwaniem dla Rosji, że staje się ona państwem ekspansywnym, uważającym, że obszar poradziecki jest jej naturalną strefą wpływów? Czy promocja demokracji w odniesieniu do Rosji jest polityka, która nie przyniesie rezultatu z uwagi na brak jasno sprecyzowanych celów strategii Zachodu wobec Rosji? Czy w działaniach Rosji mocarstwowość ma większe znaczenie niż stworzenie podstaw porządku demokratycznego? Są to bardzo istotne pytania z punktu widzenia praktyki politycznej, ale również teorii polityki międzynarodowej.

Neoimperializm Rosji pod rządami Władimira Putina, rozumiany przede wszystkim jako odmowa uznania pełnej suwerenności państw powstałych w wyniku rozpadu Związku Radzieckiego (taki sposób rozumienia polityki neoimperialnej jest przyjęty m.in. w: Cadier, Light, 2015), co może skutkować działaniami Kremla w zakresie zmiany granic międzynarodowych, podważaniem legitymizacji rządów i terytorialnej integralności państw sąsiadujących z Rosją (Bugajski, 2014), ma swoje źródła, głównie wewnętrzne. Rosja przez wieki prowadziła politykę kolonizacji państw sąsiedzkich, wobec czego nostalgia Putina za utraconym imperium i dążenie do jego przywrócenia nie powinny dziwić (szerzej: Herpen, 2014). Konflikty w Czeczenii i Gruzji oraz wojna hybrydowa na Ukrainie są działaniami Rosji, które wynikają z konstatacji Putina, że rozpad Związku Radzieckiego był największą katastrofą geopolityczną XX wieku (Putin, 2005). Jednym z elementów aktywności Moskwy w tym zakresie jest realizacja wielkiej strategii zniszczenia Partnerstwa Wschodniego Unii Europejskiej i zastapienia go przez własną politykę sąsiedztwa (Emerson, Kostanyan, 2012). Zrealizowanie tego celu byłoby katastrofalne dla polityki wschodniej Unii Europejskiej, ale również zatrułoby relacje Unii z Rosją. Przede wszystkim miałoby negatywny wpływ na takie państwa, jak Armenia, Mołdawia czy Ukraina, gdyż byłyby one odcięte od możliwości pełniejszego włączenia się w konkurencyjną gospodarkę globalną. Co więcej, państwa te byłyby poddane geopolitycznemu przymusowi ze strony Rosji, która odgrywa rolę hegemona w ramach powołanych przez siebie instytucji współpracy na obszarze poradzieckim. Przykładem może być Euroazjatycka Unia Gospodarcza (EUG) ${ }^{2}$, która powstała w 2015 roku i która po Euroazjatyckiej Unii Celnej i Wspólnej Przestrzeni Gospodarczej jest kolejną inicjatywą mającą za zadanie uzależnienie państw obszaru poradzieckiego. EUG nie jest skutecznym narzędziem integracji gospodarczej, ale jest traktowana przez Rosję jako instrument realizacji politycznych ambicji Władimira Putina. W odróżnieniu od Unii Europejskiej, która w swojej polityce sąsiedztwa stosuje przede wszystkim marchewkę, czyli zachęty do wewnętrznej modernizacji, Rosja w ramach EUG stosuje politykę kija, czyli wymuszania politycznej uległości wobec Kremla (Jarosiewicz, Fischer, 2015).

Pomimo tego, że Unii Europejskiej nie można nadal ujmować jako tradycyjnej potęgi, to Rosja traktuje Partnerstwo Wschodnie, którego celem jest zbliżenie państw Europy Wschodniej do zinstytucjonalizowanej Europy, jako wyzwanie zmierzające do pomniejszenia wpływów Moskwy na obszarze poradzieckim. Negatywny stosunek Rosji jest więc podyktowany obawą przed rozszerzeniem strefy demokracji, co w dłuższej perspektywie może skutkować zachwianiem podstawami reżimu Putina

2 Państwami członkowskimi Euroazjatyckiej Unii Gospodarczej są: Armenia, Białoruś, Kazachstan, Kirgistan i Rosja. 
lub jego następców. Rozprzestrzenianie się wartości, na których oparty jest projekt europejski, mogłoby bowiem ostatecznie doprowadzić do eksportu kolorowej rewolucji do Rosji. Po raz kolejny można dojść do przekonania, że działania Rosji są nie tyle podyktowane potrzebą realizacji strategii zagranicznej, ile wynikają przede wszystkim z pobudek wewnętrznych. Politykę Moskwy, której początków można się doszukiwać w połowie pierwszej dekady XXI wieku, można nazwać nowym powstrzymywaniem (Walker, 2015, s. 43-47). Celem Rosji jest przeciwdziałanie sukcesowi reform w takich państwach, jak Gruzja, Ukraina czy Kirgistan, które doświadczyły kolorowych rewolucji. Po odsunięciu Wiktora Janukowycza od władzy Moskwa dąży więc do ciągłego destabilizowania sytuacji na Ukrainie. Nie jest to podyktowane jedynie neoimperializmem Putina, bo w taki sposób można tłumaczyć aneksję Krymu i wspieranie rebeliantów we wschodniej Ukrainie. Rosja chce przeciwdziałać sukcesowi procesu demokratyzacji Ukrainy, bo zagrażałoby to skorumpowanemu systemowi rozwijanemu przez Kreml.

Analizując Unię Europejskąjako aktora międzynarodowego, rywalizację z Rosją na obszarach wspólnego sąsiedztwa można teoretycznie wyjaśnić dwojako. Z jednej strony, można posłużyć się realizmem, który jest najbardziej adekwatny do zrozumienia konfliktów, jakkolwiek rzadko jest wykorzystywany do uchwycenia istoty integracji w ramach Unii Europejskiej. Z drugiej strony, można przyjąć podejście normatywne, które byłoby zgodne zarówno z liberalizmem, jak i konstruktywizmem społecznym.

\section{Konkluzje}

Rekapitulując, należy podkreślić, że Europejska Polityka Sąsiedztwa stanowi istotny element w kształtowaniu pozycji międzynarodowej UE. Jak podkreślił w 2008 roku członek Komisji Europejskiej, odpowiedzialny za poszerzenie, Olli Rehn, polityka poszerzenia jest najważniejszym narzędziem Unii Europejskiej jako miękkiej potęgi (soft power), której siła przyciagania działała jako zachęta na rzecz stabilności i demokracji w państwach Europy Środkowo-Wschodniej, a później na Bałkanach (Juncos, 2011, s. 92). Z tego punktu widzenia brak perspektywy członkostwa dla europejskich państw sąsiedzkich (w szczególności dla państw Partnerstwa Wschodniego) być może stanowi największe wyzwanie dla skuteczności Europejskiej Polityki Sąsiedztwa.

Możliwości oddziaływania Unii Europejskiej w związku z poszerzeniem nie dotyczą tylko państw aplikujących o członkostwo, ale również ich sąsiadów. Akcesja państw Europy Środkowo-Wschodniej (Polska, Węgry, Czechy, Słowacja, Słowenia, Litwa, Łotwa i Estonia) oraz Cypru i Malty w 2004 roku, Bułgarii i Rumunii w 2007 roku i Chorwacji w 2013 roku skutkowała przyjęciem w 2003 roku Europejskiej Polityki Sąsiedztwa, celem której jest dążenie do stabilizacji politycznej, gospodarczej i w zakresie bezpieczeństwa wschodnich i południowych sąsiadów Unii Europejskiej (Commission, 2003). Cele te zostały również potwierdzone w Strategii Globalnej UE przyjętej w 2016 roku. Chciano przez to uniknąc stworzenia nowych linii podziału pomiędzy zintegrowaną Europą a państwami Europy Wschodniej, Bliskiego Wschodu i Afryki Północnej. Główną przyjętą zasadą określającą relacje z partnerami była dyferencjacja, co po raz kolejny świadczyło o całościowym podejściu Unii, tzn. zarówno 
w aspekcie politycznym, jak i gospodarczym, do stosunków z państwami trzecimi. $\mathrm{Z}$ uwagi na stawiane cele, jak i stosowane metody, Unia, realizująca EPS, może być definiowana jako potęga cywilna (Podraza, 2015, s. 79-80). Wiąże bowiem wyraźnie stabilizację wewnętrzną państw partnerskich oraz w ramach wspólnej integrującej się strefy współpracy z promocją takich wartości, jak demokracja, pluralizm, poszanowanie praw człowieka, wolności obywatelskie, rządy prawa i podstawowe standardy pracy. W takiej perspektywie Unia może być również traktowana jako potęga normatywna. Koncepcja ta została zaproponowana przez Iana Mannersa w 2002 roku (Manners, 2002). Jakkolwiek Manners ukazuje ją jako alternatywę dla przeciwstawnych pojęć potęgi cywilnej i militarnej, to jednak trudno nie zgodzić się z opinią Thomasa Dieza, że mieści się ona w nurcie dyskusji o potędze cywilnej (Diez, 2005). Można twierdzić, że propozycja Mannersa stanowi rozwinięcie tematu potęgi cywilnej (Rees, 2011, s. 25-26). W ujęciu normatywnym Unia Europejska dokonuje dyfuzji wartości, jak trwały pokój, wolność, demokracja, prawa człowieka, rządy prawa, równość, solidarność społeczna, zrównoważony rozwój i dobre zarządzanie, które stanowiąjej podstawę normatywną w celu stworzenia bardziej pokojowego świata. Zgodnie z propozycją Mannersa, fakt, że Unia jest stworzona na podstawie normatywnej, predestynuje ją do działania na arenie międzynarodowej w sposób normatywny (Manners, 2002, s. 252). Analiza ról międzynarodowych Unii Europejskiej powinna więc uwzględniać aspekt ontologiczny, tzn. nie tyle zwracać uwagę na to, co Unia robi i lubi, ale przede wszystkim - czym jest. Akcentuje się przez to wymiar ideologiczny i tożsamościowy Unii jako wyjątkowej potęgi, która dąży do zmiany tego, co uważane jest za normalne w stosunkach międzynarodowych bez polegania na materialnych zachętach lub sile fizycznej (Toje, 2011, s. 8).

Odnosząc się do EPS, należy zaznaczyć, że żaden z kryzysów, który występował w momencie powołania Europejskiej Polityki Sąsiedztwa w 2004 roku, nie został rozwiązany. Co więcej, zarówno południowe, jak i wschodnie sąsiedztwo jest bardziej niestabilne i niebezpieczne niż w 2004 roku. Kryzys w sąsiedztwie UE stał się swego rodzaju normą w regionie objętym tą polityką (Witney, Dennison, 2015).

\section{Bibliografia}

Bugajski J. (2014), Russia's Transformation, „The Journal of International Security Affairs”, nr 27, http://www.securityaffairs.org/issues/number-27/russias-transformation.

Cadier D., Light M. (red.) (2015), Russia's Foreign Policy. Ideas, Domestic Politics and External Relations, Basingstoke.

Cameron F. (2003), The European Union and global governance, EPC Working Paper, European Policy Centre, Brussels.

Commission of the European Communities, Communication From The Commission To The Council And The European Parliament. Wider Europe - Neighbourhood: A New Framework for Relations with our Eastern and Southern Neighbours, Brussels, 11.3.2003, COM(2003) 104 final.

Cremona M. (2004), The Union as a global actor: roles, models and identity, „Common Market Law Review", nr 41.

Diez T. (2005), Constructing the Self and Changing Others: Reconsidering 'Normative Power Europe', ,Millennium - Journal of International Studies”, 3. 
Edwards G., Nuttall S. (1994), Common Foreign and Security Policy, w: Maastricht and Beyond. Building the European Union, red. A. Duff, J. Pinder, R. Pryce, London-New York.

Emerson M., Kostanyan H. (2012), Putin's Grand Design to Destroy the EU's Eastern Partnership and Replace It with a Disastrous Neighbourhood Policy of His Own, CEPS Commentary, Centre for European Policy Studies, Brussels.

Fukuyama F. (1996), Koniec historii, Wydawnictwo Zysk i S-ka, Poznań.

Hill Ch. (1998), Closing the capabilities-expectations gap?, w: A common foreign policy for Europe?, red. J. Peterson, H. Sjursen, Routledge, London.

Jarosiewicz A., Fischer E. (2015), Eurazjatycka Unia Gospodarcza - więcej polityki, mniej gospodarki, „Komentarze Ośrodka Studiów Wschodnich”, nr 157, 20 stycznia 2015, http://www. osw.waw.pl/pl/publikacje/komentarze-osw/2015-01-20/eurazjatycka-unia-gospodarcza-wiecej-polityki-mniej-gospodarki, 20.01.2015.

Juncos A.-E. (2011), Power Discourses and Power Practices: The EU's Role as a Normative Power in Bosnia, w: Normative Power Europe: Empirical and Theoretical Perspectives, red. R. G. Whitman, Palgrave Macmillan, Basingstoke.

Koutrakos P. (2003), Constitutional idiosyncrasies and political realities: the emerging security and defense policy of the European Union, „Columbia Journal of European Law”, vol. 10, nr 1.

Kubilius A., Czy Zachód ma dtugoterminowq strategię, która nie dopuści do zwycięstwa Putina na Ukrainie?, „Gazeta Wyborcza/Magazyn Świąteczny”, 14 lipca 2017, http://wyborcza.pl/ magazyn/7,124059,22095808,czy-zachod-ma-dlugoterminowa-istrategie-ktora-nie-dopusci. html, 14.07.2017.

Lesińska M., Stępniewski T. (2016), Specyfika wschodniej granicy Unii Europejskiej z perspektywy bezpieczeństwa i rozwoju, „POLITEJA. Pismo Wydziału Studiów Międzynarodowych i Politycznych Uniwersytetu Jagiellońskiego", $\mathrm{nr} 41$.

Manners I. (2002), Normative Power Europe: A Contradiction in Terms?, „Journal of Common Market Studies", 2.

Peterson J. (2008), The EU as a global actor, w: The European Union: how does it work?, red. E. Bomberg, J. Peterson, A. Stubb, Oxford University Press, Oxford.

Podraza A. (2001), Wspólna Polityka Zagraniczna i Bezpieczeństwa: Unia Europejska potęga militarna?, w: Traktat Nicejski, red. A. Podraza, Towarzystwo Naukowe Katolickiego Uniwersytetu Lubelskiego, Lublin.

Podraza A. (2003), Europejska Polityka Bezpieczeństwa i Obrony (EPBiO): Unia Europejska w poszukiwaniu tożsamości na arenie międzynarodowej, w: Integracja europejska - instytucje - polityka - prawo. Ksiega pamiatkowa dla uczczenia 65-lecia profesora Stanisława Parzymiesa, red. G. Michałowska, Wydawnictwo Naukowe Scholar, Warszawa.

Podraza A. (2015), Towards a New System of Global Democratic Governance: the Transatlantic Security Community and the Role in Democracy Promotion in the $21^{\text {st }}$ Century, w: Global Challenges to the Transatlantic World, red. C. Crespo, D. Silander, D. Wallace, I. Albella, Instituto Franklin - UAH, Alcala de Henares-Madrid.

Prezydent Estonii w czasie Global Forum w Warszawie, 7.07.2017, http://tvn24bis.pl/, 7.07.2017.

Prodi R. (2002), A Wider Europe - A Proximity Policy as the key to stability, „Peace, Security And Stability - International Dialogue and the Role of the EU", Sixth ECSA-World Conference. Jean Monnet Project, Brussels, 5-6 December 2002, www.europa.eu/rapid/press-release_ SPEECH-02-619_en.doc, 20.07.2017.

Przeglad europejskiej polityki sqsiedztwa (EPS): zacieśnione partnerstwo na rzecz silniejszego sqsiedztwa, Komisja Europejska - Komunikat prasowy, Bruksela, 18 listopada 2015, http:// europa.eu/rapid/press-release_IP-15-6121_pl.htm.

Putin deplores collapse of USSR, 25.04.2005, http://news.bbc.co.uk/2/hi/4480745.stm.

Rees W. (2011), The US-EU Security Relationship. The Tensions between a European and a Global Agenda, Palgrave Macmillan, Basingstoke. 
Rummel R. ( 2002), From weakness to power with the ESDP?, „European Foreign Affairs Review”, nr 7.

Sakwa R. (2015), The death of Europe? Continental fates after Ukraine, „International Affairs”, vol. 91 , nr 3 .

Stahl B., Boekle H., Nadoll J., Jóhannesdóttir A. (2004), Understanding the Atlanticist-Europeanist divide in the CFSP: comparing Denmark, France, Germany and the Netherlands, „European Foreign Affairs Review", nr 9.

Światowe tendencje do 2030 r.: czy UE jest $w$ stanie sprostać przyszłym wyzwaniom?, „Europejski System Analiz Strategicznych i Politycznych (ESPAS)”, Luksemburg 2017, http://espas.eu/ orbis/sites/default/files//generated/document/en/espas-report-2015pl.pdf.

Toje A. (2011), The European Union as a Small Power. After the Post-Cold War, Palgrave Macmillan, Basingstoke.

Treacher A. (2004), From civilian power to military actor: the EU's resistable transformation, „European Foreign Affairs Review", nr 9.

Van Herpen M.-H. (2005), Putin's Wars: The Rise of Russia's New Imperialism, Lanham 2014.

Walker Ch. (2015), The New Containment. Undermining Democracy, „World Affairs”, vol. 178, nr 1.

Warszawski D., Arabów droga przez mękę. Dlaczego arabskie konflikty sq tak krwawe, 14 lipca 2017, „Gazeta Wyborcza / Magazyn Świąteczny”, http://wyborcza.pl/magazyn/7,124059,22096793, arabow-droga-przez-meke-dlaczego-arabskie-konflikty-sa-tak.html, 20.07.2017.

Witney N., Dennison S. (2015), Europe's Neighbourhood: Crisis as the New Normal, „Policy Memo”, European Council on Foreign Relations, London.

Zięba R. (2003), Unia Europejska jako aktor stosunków międzynarodowych, Wydawnictwo Naukowe Scholar, Warszawa.

\section{Streszczenie}

Unia Europejska boryka się z licznymi kryzysami o charakterze wewnętrznym i zewnętrznym, które mogą wpłynąć na jej funkcjonowanie w przyszłości. Ich skutki mogą podważyć obecny model integracji i doprowadzić nawet do znaczącej transformacji UE oraz wpłynąć na jej międzynarodową pozycję. U podstaw obecnych kryzysów leżą poważne różnice zdań pomiędzy państwami członkowskimi co do radzenia sobie z wyzwaniami tak wewnętrznymi, jak i zewnętrznymi stojącymi przed Unią Europejską. Do najważniejszych można zaliczyć kryzys w strefie euro, stosunek do uchodźców i migrantów z Bliskiego Wschodu i Afryki oraz zróżnicowane podejście do Rosji w związku z aneksją Krymu i konfliktem we wschodniej Ukrainie. Wszystkie one są ilustracją głębokich podziałów nie tylko pomiędzy państwami członkowskimi, ale również w ramach poszczególnych państw.

Słowa kluczowe: Unia Europejska, międzynarodowa pozycja Unii Europejskiej, wschodnie sąsiedztwo, południowe sąsiedztwo

\section{The EU's international policy vs. the instability of the southern and eastern neighbourhood}

\section{Summary}

The European Union is facing numerous internal and external crises which may affect its future operations. The crises may undermine the present integration model. They may even 
result in the EU's considerable transformation and exert impact upon its international position. The crises stem from member states' vast differences of opinion on methods for dealing with the internal and external challenges. The most critical of the challenges include the Eurozone crisis, attitude towards refugees and migrants from the Near East and Africa, and diverse approaches towards Russia in connection with the annexation of Crimea and with the conflict in Eastern Ukraine. They all illustrate a deep rift not only among member states but also within individual countries of the EU.

Key words: European Union, EU's international policy, Eastern neighbourhood, Southern neighbourhood. 